\title{
Monitoring Performance of Low Impact Development Measures Implemented at the Conestoga College South Campus
}

\author{
Ann Sychterz, Tim Schill and Brian Verspagen
}

\begin{abstract}
Through a system of bioswales, infiltration galleries, detention ponds, oil-grit separators and a cooling trench, the discharge from a new development can match or exceed in quality the pre-development discharge. These considerations underlie the stormwater management design for Conestoga College's South Campus in Cambridge, Ontario. The site was equipped with bioswale infiltration gallery inspection ports, seepage collection system monitoring locations, groundwater monitoring locations, temperature monitors and level monitors. The data was collected for a period of 6 months in 2012 as part of a 5 y monitoring program to assess the performance of the design implementation. In conjunction with rainfall and ambient temperature data, the effectiveness of the stormwater system to reduce the volume of runoff, the peak flow and the discharge temperature was determined via statistical analysis. In addition to meeting the runoff and peak flow control objectives, the temperature differential across the monitoring stations demonstrated that there was an average cooling of the runoff. The temperature differential was compared to initial conditions such as ambient temperature, initial runoff temperature and water level. Each of these relationships fitted a linear regression, which indicates a good method for predicting future performance.
\end{abstract}

Keywords: LID, performance monitoring, stormwater discharge, thermal mitigation, water quality.

\section{Introduction}

The Conestoga College South campus is located to the south of the Doon campus. The overall site has an area of 53.25 ha, of which phase 1 is an area of $18.4 \mathrm{ha}$. The lands were actively utilized for agricultural purposes both prior to and during their ownership by Conestoga College. The site featured minimal vegetation limited to the perimeter with two internal hedgerows and an ephemeral watercourse draining through the southern portion of the site. The site is approximately triangular in shape and is bounded by Highway 401 to the northwest, Morningside Drive to the northeast, and Fountain Street to the south (Verspagen, 2009a). The Cambridge campus represents an expansion by Conestoga College to grow the Doon campus by the construction a separate campus south of Highway 401 at the intersection of Fountain Street and Dickie Settlement Road. The monitoring program undertaken between June and December 2012 was consistent with the Region of Waterloo's conditions of site plan approval (Verspagen 2009b).

Developing a functional stormwater management system requires a good understanding of existing conditions, a wellmodelled design, and field experimentation for design confirmation. The conditions of site plan approval required by the Region of Waterloo and the City of Cambridge necessitated the use of low impact development (LID) measures in the stormwater management system design to meet the discharge targets established for development in the Blair Creek watershed.
LID measures including bioswales, infiltration galleries, detention basins, and a cooling trench were utilized in the approved design. Bioswales provide filtration for water quality improvements, infiltration of captured runoff, and attenuation of peak flows in the swale itself for runoff that drains via the overflow. Infiltration galleries provide at-source groundwater recharge. Detention ponds aid with sedimentation and the attenuation of peak flows. Cooling trenches comprised of subsurface rock cribs have the potential to decrease the temperature of discharge through contact with the trench media.

Some published LID performance data is available and was considered as part of the design development phase. Bioretention basins and bioswales have been studied for their ability to provide thermal mitigation and runoff quantity control. In Baltimore, an underground stormwater detention system was built to reduce the runoff temperature from $\sim 25^{\circ} \mathrm{C}$ to a discharge temperature of $20^{\circ} \mathrm{C}$ (Natarajan et al. 2010). This was achievable for the whole year except in July and August, when the maximum reduction was to $19.7^{\circ} \mathrm{C}$. Vegetative strips are unlike other surface stormwater control measures since they can reduce runoff temperature as well as velocity (Winston et al. 2011). In Asheville, North Carolina a trout-sensitive area was monitored and it was found that smaller bioretention cells reduced the peak and average temperature and flow, whereas larger cells only reduced the peak temperature and flow (Jones at al. 2009). Bioretention basins are also less likely to cause mounding and permanent effects to the water table, which can affect substructures (Endreny et al. 2009). Thus bioretention basins are considered more effective for

Sychterz, A., T. Schill and B. Verspagen. 2014. "Monitoring Performance of Low Impact Development Measures Implemented at the Conestoga College South Campus." Journal of Water Management Modeling C371. doi: 10.14796/JWMM.C371.

() CHI 2014 www.chijournal.org ISSN: 2292-6062 
temperature and volume reduction than are wet ponds (Herb et al. 2009). In cold weather conditions, the hydraulic conductivity was observed to increase with increased soil moisture content when air temperatures were $<0^{\circ} \mathrm{C}$ (Fach et al. 2011). Air temperatures $\leq 5^{\circ} \mathrm{C}$ had the opposite effect with increased soil moisture. Rock cribs (or cooling trenches) were studied in laboratory experiments where the temperature reduction was $\sim 2{ }^{\circ} \mathrm{C}$, which promises further reductions in larger scale urbanization projects (Thompson et al. 2008).

The performance of LID installations is not widely documented to enable reference when seeking approval from local regulatory agencies that require water quality targets to be achieved. LID measures, however, allow the stormwater to be managed closer to the source and promote an environmentally sensitive design (Ahiablame et al. 2012). LID measures can also attenuate peak discharge and reduce a site's overall runoff coefficient, runoff volume and centroid lag-to-peak (Hood et al. 2007). Future work on bioretention technology includes an emphasis on fill media composition, depth and configuration of ponds and swales, and proper maintenance to ensure future effectiveness (Davis et al. 2009).

\section{Methodology}

\subsection{Objectives}

Discharge criteria for the site were established in the Blair, Bechtel and Bauman Creek Subwatershed Study prepared by $\mathrm{CH} 2 \mathrm{M}$ Gore \& Storrie Limited, Gartner Lee Limited, Mark L. Dorfman, Planner Inc., and Schroeter and Associates, in January 1997; and the Upper Blair Creek Functional Drainage Study prepared by Stantec Consulting Ltd. in February 2009. These criteria included:

- to protect and enhance water quality and associated aquatic resources and water supplies;

- to protect and enhance groundwater quantity and quality; and

- to minimize the threat to life and destruction of property and natural resources from flooding and erosion, and preserve natural floodplain hydrologic functions.

Specific stormwater management design objectives for developments in the Blair Creek subwatershed include:

- minimize required offsite control;

maintain or reproduce predevelopment hydro geologic, hydrologic and water quality conditions by promoting pre-development infiltration and runoff characteristics (quantity and distribution);

. minimize changes to existing topography;

- minimize footprint of development (i.e. impervious areas);

- preserve and utilize natural drainage systems where appropriate;

- reduce susceptibility to downstream flooding and erosion; and
- promote pollutant removal.

Potential temperature impacts from stormwater control pond discharges to Blair Creek were also identified as being of primary concern in the subwatershed plan.

These objectives are intended to be achieved through the following approaches:

- maximize use of on-lot measures including on-lot grading, roof leader to ponding areas and soakaway pits, sump pumping of foundation drains to infiltration trenches;

- install end-of-pipe facilities that incorporate extended detention wet ponds and constructed wetlands for water quality control in accordance with the MOE (Ontario Ministry of the Environment) guidelines; and

- address the need for temperature mitigation.

\section{Stormwater Quantity}

The peak flows discharged from the site were to be less than or equal to those calculated in existing conditions for the $2 y$ through $100 \mathrm{y}$ storm events. If the impervious cover limit of $35 \%$ for the site established in the subwatershed study was exceeded, discharge runoff volume in excess of that generated under existing conditions would be required to be released at a rate that did not cause the flow in the receiving Blair Creek to exceed $0.4 \mathrm{~m}^{3} / \mathrm{s}$, as calculated using the watershed model under any storm event conditions.

An extended detention drawdown time of $96 \mathrm{~h}$ was required to discharge the runoff from the $2 \mathrm{y}$ storm from the onsite detention basins to Blair Creek. Due to the extended detention requirements, it was proposed in the subwatershed study that the allowable detention storage volume depth be increased to $3 \mathrm{~m}$ from the maximum of $1.8 \mathrm{~m}$.

\section{Stormwater Quality}

All stormwater management water quality measures were designed in accordance with the Stormwater Management Planning and Design Manual produced by the MOE in March, 2003 to meet the requirements of the level 1, or enhanced, treatment. This level of treatment requires $80 \%$ removal of TSS from the site discharge.

\section{Infiltration}

The runoff volume generated by the $25 \mathrm{~mm}$ storm under proposed conditions could not increase beyond existing conditions during a summer storm. To meet this objective, infiltration measures were distributed around the site rather than at concentrated locations. All infiltration facilities were designed to have a capacity that exceeded the existing conditions recharge volume by $15 \%$, as a factor of safety, to account for aging, compaction and potential clogging. Design of the infiltration facilities also demonstrated reasonable drawdown times of $5 \mathrm{~d}$ based on an average of 5 precipitation events each month. 


\section{Thermal Mitigation}

The maximum acceptable temperature of surface runoff was determined to be $21.2^{\circ} \mathrm{C}$. This temperature represents the average air temperature during the month of July. To provide adequate cooling of surface runoff, a 6 month travel time was considered adequate between any infiltration gallery and the receiving creek.

The stormwater management measures were designed to have the capacity to capture the surface runoff from the $25 \mathrm{~mm}$ event followed by a $12 \mathrm{~mm}$ event $24 \mathrm{~h}$ later such that all release of surface discharge to the creek was either through the infiltration galleries or the pond and cooling trench.

\subsection{Design}

\section{Drainage}

The main entry is a divided roadway featuring a wide median and traditional curb and gutter along its length. Drainage for the road is captured by catchbasins and routed along its entire length to an oil-grit separator and detention basin that provides treatment for all surface runoff from the site for phase 1. The design meets the Level 1 quality and quantity treatment requirement to provide $80 \%$ removal of TSS as required by the MOE.

Drainage from the parking lot is via sheet flow to four bioswales. The bioswales are distributed evenly across the parking lot. This results in a distributed infiltration strategy that maximizes the infiltration gallery footprint and optimizes the separation between the base of the infiltration galleries and the water table.

All rooftop runoff drains to a dedicated infiltration gallery in the south central green.

\section{Bioswales}

The design of the bioswales provides a three stage approach to drainage. The asphalt parking lots are graded towards the bioswales in all locations except for in the immediate vicinity of the barrier free parking spots. A bounding curb features regularly spaced runout locations, which facilitate the drainage of surface runoff into the bioswales. The bioswales are $3 \mathrm{~m}$ to $4 \mathrm{~m}$ wide with fully vegetated embankments. A $0.6 \mathrm{~m}$ wide ribbon of riverstone at the crest of the bioswale convolutes the flow path and provides a primary settling area for suspended sediment as the flow drains into the bioswale. The invert of the bioswale is also lined with a protective layer of riverstone and progressively finer grades of stone media comprised of $270 \mathrm{~mm}$ of $25 \mathrm{~mm}$ clear stone and 230 $\mathrm{mm}$ of pea gravel on top of a plastic subsurface chamber which stores the water as it percolates into the ground.

Runoff captured in the bioswales will infiltrate until the swale is inundated to a depth of at least $0.2 \mathrm{~m}$ above the exposed invert of the swale. Once this inundation depth is reached, water drains via regularly spaced catchbasins to the site storm sewer collection system and discharges via the detention pond.

\section{Infiltration Gallery}

Drainage from the main building rooftop and the south central green is collected and routed to an infiltration gallery in the south central green, having a capture capacity of $700 \mathrm{~m}^{3}$. The infiltration gallery is designed to capture and infiltrate all runoff from the current phase 1 building, and from the proposed future buildings which will be bordering the green, for the $25 \mathrm{~mm}$ and 2 y storm events. The large capacity of the infiltration gallery presently results in a zero runoff condition under all storm event conditions, including the 100 y storm, due to the large subsurface capacity provided.

In terms of the level of treatment provided by the proposed infiltration galleries within the central green and the bioswales, based on an assumed impervious ratio of $85 \%, 40 \mathrm{~m}^{3}$ storage is required per contributing hectare, necessitating a total of $157 \mathrm{~m}^{3}$ capture capacity in the gallery in phase 1 . A total of $1476 \mathrm{~m}^{3}$ is provided in phase 1 . The proposed infiltration galleries therefore provide treatment well in excess of that required by the MOE to achieve an enhanced level of treatment.

Overflow from the infiltration gallery discharges to the storm sewer collection system at the roundabout. In the unlikely event that surcharging of the infiltration gallery occurs under phase 1 conditions, this flow is routed to the phase 1 detention pond.

\section{Detention Pond}

The detention pond incorporates several levels of treatment as part of the treatment train process proposed for the site. All flow draining to the pond via the storm sewer is initially treated by an oil-grit interceptor designed to achieve Level 1 treatment removal for suspended sediment, oil and grease. Flow enters the pond via a forebay which features a low flow bypass outlet. The bypass outlet routes low flow directly to the pond outlet and Blair Creek without contacting the larger, thermally enriched, permanent pool.

The remainder of the pond features numerous micropools and an extended flow length to maximize settling opportunities for flow that surcharges the low flow outlet. A second outlet is located in the pond at an elevated level that features a $0.2 \mathrm{~m}$ wide weir draining to the common outlet structure.

In terms of the level of treatment provided by the proposed detention basin, based on an assumed worst case impervious ratio of $85 \%, 250 \mathrm{~m}^{3}$ storage is required per contributing hectare necessitating a total of $3934 \mathrm{~m}^{3}$ storage in the pond for phase 1 . A total of $19707 \mathrm{~m}^{3}$ is provided allowing room to grow on the campus. The detention basin presently provides treatment well in excess of that required by the MOE to achieve an enhanced level of treatment. The discharge could therefore be directed to a creek directly and meet the MOE water quality criteria in the absence of any upstream water quality controls-infiltration galleries, bioswales or oil-grit interceptors. 


\section{Cooling Trench}

The pond outlet is designed as a percolation gallery. Water is discharged from the pond via an outlet structure which is connected to a subsurface perforated pipe perpendicular to the direction of flow. This perforated pipe functions as a manifold for water to drain out of the pond across a wide subterranean flow path, through a French drain, to an existing swale parallel to Fountain Street, and the outlet from the site. The objective of the percolation gallery is to bring the temperature of the water discharged from the pond closer to that of the groundwater.

\section{Hydrologic Modeling}

\subsection{Existing Conditions}

A continuous hydrologic model was previously developed as part of the Blair, Bechtel and Bauman Creek subwatershed study. The model platform was the Guelph All Weather Storm Event Runoff (GAWSER) model (Schroeter and Associates). The existing model was field validated in the immediate vicinity of the college. Some corrections were made based on the field verified data, and the model catchment delineations were modified to best isolate the site and evaluate the performance of the proposed stormwater management measures.

\subsection{Proposed Conditions}

The model parameters for the onsite catchments were modified to represent the increased impervious area, changes in grading, and presence of the stormwater management measures representing the proposed development conditions.

The analysis was performed using both continuous and event modes for review purposes. The continuous analysis utilized climate data from 1960 through 1990 consistent with the agency model analysis used as a benchmark. The performance of the site infiltration measures was assessed using the continuous simulation and an event based analysis was performed to demonstrate compliance with the quantity control requirements.

As part of the continuous simulation, the infiltration properties of the site soils were used to calculate drawdown within the infiltration galleries between precipitation events. The continuous simulation demonstrated that the infiltration galleries would drain down within $3 \mathrm{~d}$ to $5 \mathrm{~d}$ of a typical precipitation event.

For the purposes of the event based analysis, the infiltration galleries were represented as ponds with zero outflow until the overflow elevation was achieved based on the results of the continuous simulation. This approach assumed very limited infiltration would occur during a storm event and also assumed that the infiltration gallery will be empty at the commencement of each storm. Outflow from the galleries is represented by stage discharge curves that represent outflow from the catchbasins as restricted by the outlet pipe.

A summary of the calculated site stormwater management system performance as compared to pre-construction conditions is provided in Table 1 for the continuous simulation and in Tables 2 and 3 for the event-based analysis.

Table 1 Water balance analysis summary.

\begin{tabular}{lcc}
\hline \multicolumn{1}{c}{ Water Balance Parameter } & $\begin{array}{c}\text { Preconstruction Conditions } \\
(\mathrm{mm})\end{array}$ & $\begin{array}{c}\text { Post Construction (Phase 1) } \\
\text { Conditions (mm) }\end{array}$ \\
\hline Annual Evapotranspiration & 619.8 & 502.8 \\
Annual Runoff & 87.5 & 230.9 \\
Annual Baseflow & 51.2 & 54.2 \\
Annual Net Storage & 66.1 & 0.8 \\
Annual Total Flow & 102.8 & 285.1 \\
\hline
\end{tabular}

Table 2 Summary of site peak flow.

\begin{tabular}{lcc}
\hline Design Storm & $\begin{array}{r}\text { Preconstruction Conditions } \\
\left(\mathrm{m}^{3} / \mathrm{s}\right)\end{array}$ & $\begin{array}{c}\text { Post Construction (Phase 1) } \\
\text { Conditions }\left(\mathrm{m}^{3} / \mathrm{s}\right)\end{array}$ \\
\hline $25 \mathrm{~mm}$ & 0.0308 & 0.0000 \\
$2 \mathrm{y}$ & 0.1000 & 0.0010 \\
$5 \mathrm{y}$ & 0.2117 & 0.0080 \\
$10 \mathrm{y}$ & 0.2876 & 0.0120 \\
$25 \mathrm{y}$ & 0.3836 & 0.0140 \\
$50 \mathrm{y}$ & 0.4630 & 0.0160 \\
$100 \mathrm{y}$ & 0.5454 & 0.0170 \\
\hline
\end{tabular}

Table 3 Summary of site runoff volume.

\begin{tabular}{lcc}
\hline Design Storm & $\begin{array}{c}\text { Preconstruction Conditions } \\
(\mathrm{mm})\end{array}$ & $\begin{array}{c}\text { Post Construction (Phase 1) } \\
\text { Conditions (mm) }\end{array}$ \\
\hline $25 \mathrm{~mm}$ & 2.91 & 0 \\
$2 \mathrm{y}$ & 7.76 & 0.926 \\
$5 \mathrm{y}$ & 15.61 & 6.299 \\
$10 \mathrm{y}$ & 21.15 & 10.037 \\
$25 \mathrm{y}$ & 28.32 & 13.651 \\
$50 \mathrm{y}$ & 34.41 & 15.650 \\
$100 \mathrm{y}$ & 40.66 & 17.338 \\
\hline
\end{tabular}

\subsection{Stormwater Monitoring}

Limited data was available that would support the performance of the proposed infiltration galleries, bioswales and cooling trenches. A monitoring program was required to demonstrate compliance with the identified subwatershed objectives. The monitoring program implemented at the college comprises observations of the performance of the bioswales, infiltration galleries and detention pond, and monitoring of the flow and temperature of the discharge at the site outlet.

\section{Bioswale Monitoring}

A continuously recording level logger and a temperature probe were installed at the outlet manhole from the parking area. Recorded depths were converted to flows using a rating table.

\section{Infiltration Gallery Monitoring}

A continuous water level logger was installed to monitor flow from the south central green overflow. Since this gallery should not overflow under any common storm event ( $<12 \mathrm{~mm}$ accumu- 
lation), evidence of flow from this manhole indicates that the infiltration gallery is not functioning properly.

\section{Detention Pond Monitoring}

Continuous water level loggers were installed to monitor flow through the detention pond. Level loggers and temperature probes were placed at the inlet and the outlet. Stage discharge curves were developed to convert depth of flow to actual flow.

\section{Site Outlet Monitoring}

A weir, level logger and temperature probe were installed in the outlet channel from the site near Fountain Street. Stage discharge curves were developed to convert depth of flow to actual flow.

\section{Results and Discussion}

\subsection{Overall Results}

Each segment of the stormwater management system from the parking lot of the proposed building to Blair Creek achieves a runoff temperature drop, with the exception of the detention basin. Discarding the negative temperature differentials from the winter, the largest average temperature drop was between the pond outlet structure and the outlet channel from the cooling trench, with a total average drop of $\sim 1^{\circ} \mathrm{C}$ across the system (Table 4). Table 4 summarizes the continuous temperature data from June to September 18, at which point the media in the cooling trench was no longer cooler than the ambient air temperature.

Table 4 Summary of temperature monitoring results.

\begin{tabular}{lcccc}
\hline \multicolumn{1}{c}{ Start Node } & End Node & Element & Average Drop $\left({ }^{\circ} \mathrm{C}\right)$ & Maximum Drop $\left({ }^{\circ} \mathrm{C}\right)$ \\
\hline Parking Lot & Pond Inlet & Storm Sewer & 0.5 & 9.4 \\
$\begin{array}{l}\text { Catchbasin } \\
\text { Pond Inlet }\end{array}$ & Pond Outlet & Detention Pond & -1.2 & 11.3 \\
Pond Outlet & Outlet Channel & Cooling Trench & 4.2 & 10.2 \\
\hline
\end{tabular}

The average runoff temperature observed at the outlet from the stormwater management cooling trench was $15^{\circ} \mathrm{C}$, or approximately that of groundwater. Given the average runoff temperature and temperature drop through the system during the monitoring period, this would indicate that the system treats the runoff to mimic groundwater temperatures to be discharged into the receiving cold water creek.

\subsection{Time Series Results}

Understanding of the behaviour of this stormwater management system can be derived from the time series data obtained over the 6 month period from June to December of 2012. Figure 1 compares the Roseville daily precipitation, the moving average of the 10 min interval ambient air temperature, and the temperature of the discharge at the outlet of the cooling trench. Increases in precipitation correspond to a peak in the discharge water temperature at monitoring station SW6. Larger volumes of runoff were observed to more significantly affect the temperature of the discharge than smaller events. When the ambient air temper- ature is warmer than the temperature of the media in the cooling trench, the temperature of the discharge decreases during rainfall (June to September). Conversely, when the cooling trench media is warmer than the ambient air temperature, the temperature of the discharge is warmed (September to December) further mimicing groundwater temperature characteristics.

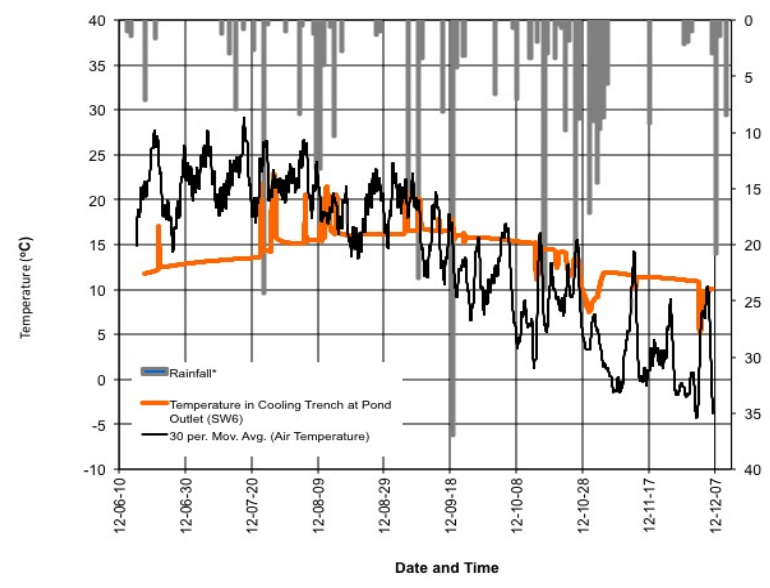

Figure 1 Time series monitoring results of rainfall, ambient temperature, and rock crib temperature drop.

\subsection{Peak Events}

Of the rainfall events in this 6 month period, four were further investigated. The intensity and duration of the storm event correspond to a flow response of the system.

Figure 2 illustrates the effect of an intense rainfall event and a lag of $12 \mathrm{~h}$ is seen in the temperature at the outlet of the cooling trench. The temperature at the inlet of the storm sewer is almost instantly affected by the increase in runoff. The flow from the pond outlet is only slightly increased due to the sudden rainfall event.

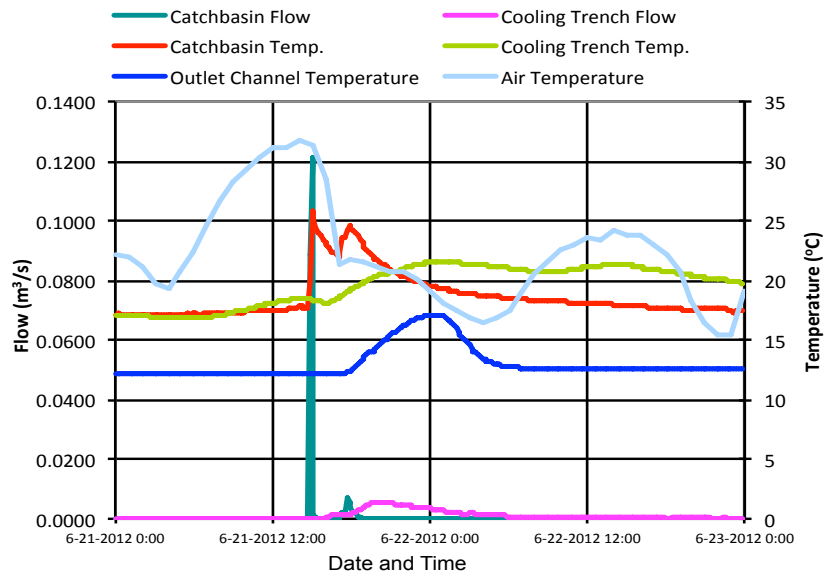

Figure 2 Peak rainfall event on 20120621.

The Figure 3 event occurred on a warmer day where neither the influx of runoff nor the variations in temperature affect the temperature at the pond or rock crib outlets. 


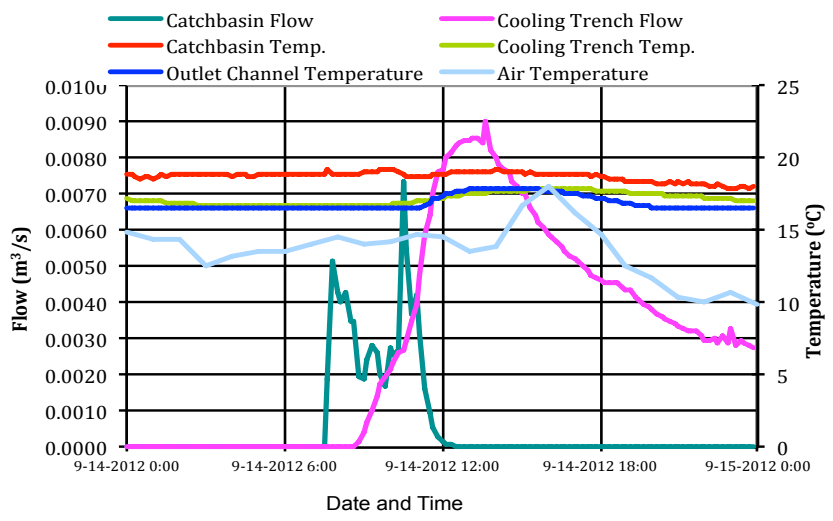

Figure 3 Peak rainfall event on 20120914.

The rainfall event in Figure 4 began with a spike in runoff, followed by a lower intensity but longer duration storm, causing a plateau effect in the flow response. The rainfall events in Figure 3 and Figure 4 took place over a longer period of time and resulted in a greater precipitation accumulation.

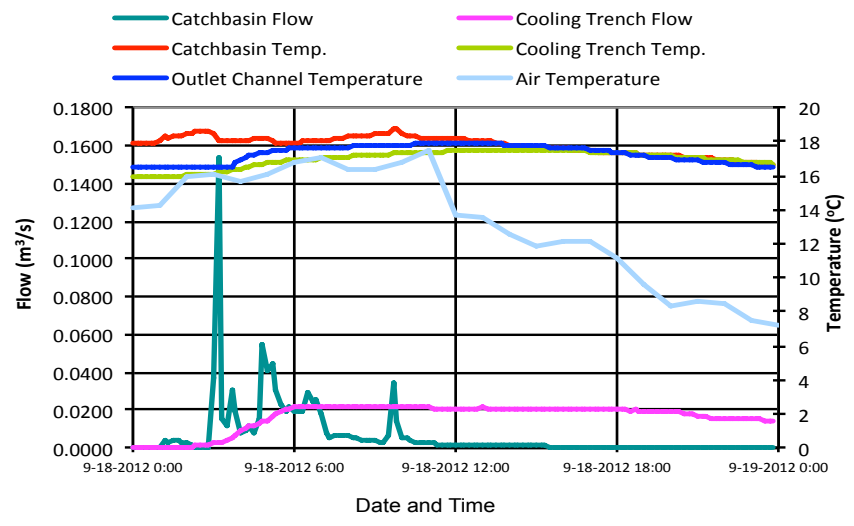

Figure 4 Peak rainfall event on 20120918.

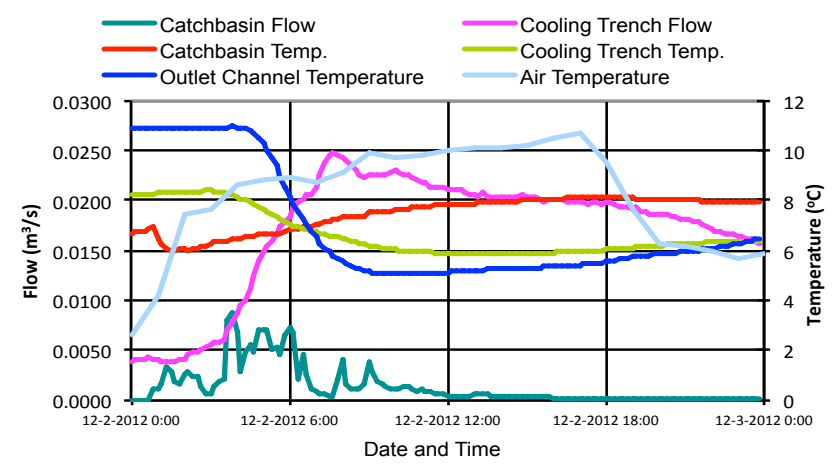

Figure 5 Peak rainfall event on 20121202.

\subsection{Sensitivity Analysis}

The temperature differences across the storm sewer between the catchbasin and the pond inlet, detention pond between the pond inlet and outlet, and the cooling trench between the pond outlet and the site outlet channel were compared to ambient temperature and to initial runoff temperature (Figure 6 and Figure 7).

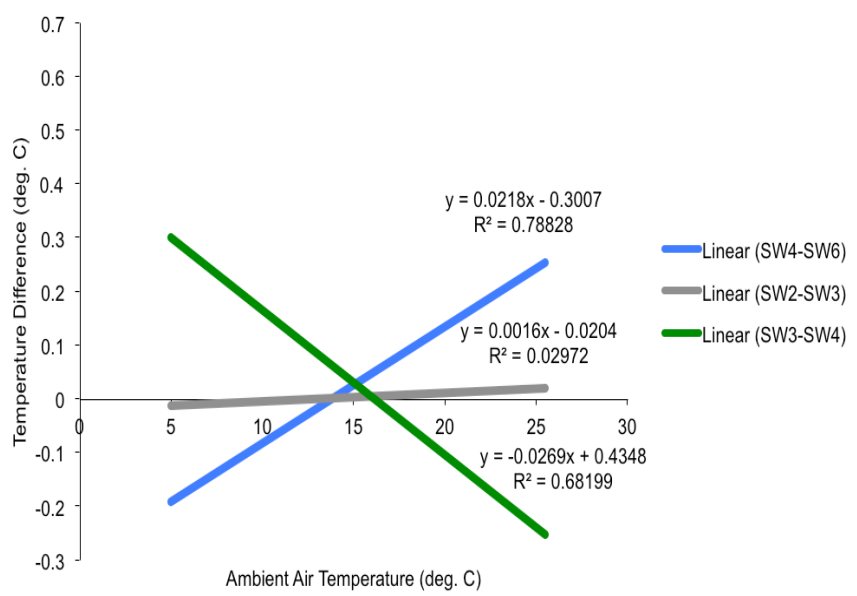

Figure 6 Normalized temperature difference across the storm sewer, detention pond and cooling trench during 20 storm events with regards to ambient air temperature.

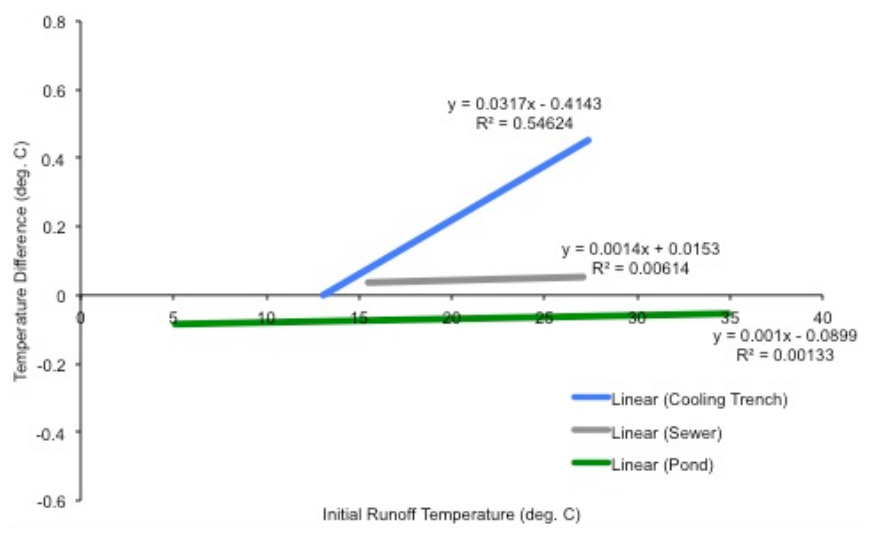

Figure 7 Normalized temperature difference across the bioswale, detention pond, and rock crib during twenty storm events with regards to initial SW4 temperature.

For comparison purposes, the temperature difference was normalized by the temperature of the upstream monitoring station. A linear regression was applied to the data. The storm sewer and cooling trench relationships exhibited findings consistent with the average temperature drop across the data set from June until September 18, 2012, from Table 4.

Of the stormwater management components, the cooling trench has the highest degree of temperature drop given an increase in air temperature. The storm sewer provides a minor contribution to the temperature drop. The detention pond, however, thermally enriches the runoff during periods of higher ambient temperature.

This trend analysis allows for a quick calculation of the amount of available cooling from the stormwater system since ambient air temperature is readily available. 
A more significant trend can be observed between the normalized temperature difference and the initial runoff temperature per reach than any of the other treatment measures in the stormwater system. Again, the temperature difference across the storm sewer is minimal and is less influenced by external parameters. The detention pond provides an approximately constant increase in temperature to the stormwater given any initial water temperature.

Since the behaviour of the storm sewer and the detention pond are constant, it can be concluded that knowing the initial temperature of the stormwater at any point along the system can help predict the amount of cooling attainable by the cooling trench.

\section{Conclusions}

The monitoring results from June until December 2012 showed that the bioswales, stormwater storage ponds and the rock crib were effective in providing peak flow and runoff volume management and thus to maintain a water balance similar to preconstruction conditions to maintain baseflow in Blair Creek. The monitoring program also demonstrated that the system is effective at reducing the temperature of the discharge from the site by up to $10^{\circ} \mathrm{C}$ during the peak of any given precipitation event with a cumulative long term average of $\sim 1{ }^{\circ} \mathrm{C}$ over the system. Given the average runoff temperature from the parking lot surface is reduced to $15^{\circ} \mathrm{C}$, this would be adequate cooling for the runoff to mimic groundwater temperature characteristics prior to discharge to Blair Creek. When air temperatures dropped to $<15^{\circ} \mathrm{C}$, the cooling trench began to warm the runoff again mimicking groundwater temperature characteristics. The stormwater management system is thus able to absorb the rainfall event peaks in terms of flow, volume, and temperature thereby protecting water quality in the receiving Blair Creek.

\section{References}

Ahiablame, L. M., B. A. Engel and I. Chauby. 2012. “Effectiveness of Low Impact Development Practices: Literature Review and Suggestions for Future Research." Water, Air and Soil Pollution 223 (7): 4253-73.

Ann Sychterz University of Waterloo, Waterloo, Ontario.

Tim Schill Conestoga College Institute of Technology \& Advanced Learning, Kitchener, Ontario.

Brian Verspagen WalterFedy, Kitchener, Ontario.
Davis, A. P., W. F. Hunt, R. G. Traver and M. Clar. 2009. "Bioretention Technology: Overview of Current Practice and Future Needs." Journal of Environmental Engineering 135 (3): 10917.

Endreny, T. and V. Collins. 2009. “Implications of Bioretention Basin Spatial Arrangements on Stormwater Recharge and Groundwater Mounding." Ecological Engineering 35:670-7.

Fach, S., C. Englehard, N. Wittke and W. Rauch. 2011. “Performance of Infiltration Swales with regard to Operation in Winter Times in an Alpine Region." Water Science and Technology 63:2658-65.

Herb, W. R., O. Mohseni and H. G. Stefan. 2009. "Simulation of Temperature Mitigation by a Stormwater Detention Pond." Journal of the American Water Resources Association 45:1164-78.

Hood, M. J., J. C. Clausen and G. S. Warner. 2007. “Comparison of Stormwater Lag Times for Low Impact and Traditional Residential Development." Journal of the American Water Resources Association 43:1036-46.

Jones, M. P. and W. F. Hunt. 2009. Bioretention Impact on Runoff Temperature in Trout-Sensitive Waters. Journal of Environmental Engineering 135:577-85.

Natarajan, P. and A. P. Davis. 2010. "Thermal Reduction by an Underground Stormwater Detention System." Journal of Environmental Engineering 136:520-6.

Thompson, A. M., A. J. Vandermuss, J. M. Norman and A. RoaEspinosa. 2008. "Modeling the Effect of a Rock Crib on Reducing Stormwater Runoff Temperature." Transactions of the American Society of Agricultural and Biological Engineers 51:947-60.

Verspagen, Brian. 2009a. In Stormwater Management Report: Conestoga College Cambridge Campus Phase 1, 1-13. Kitchener, Ontario: WalterFedy.

Verspagen, Brian. 2009b. In Stormwater Management System Monitoring and Maintenance Plan: Conestoga College Cambridge Campus Phase 1, 1-10. Kitchener, Ontario: WalterFedy.

Winston R. J., W. F. Hunt and W. G. Lord. 2011. "Thermal Mitigation of Urban Stormwater by Level Spreader-Vegetative Filter Strips." Journal of Environmental Engineering 137:707-16. 